\title{
Biodiversity profile \\ Floristic diversity and conservation strategies in cold desert of western Himalaya, India
}

\author{
Sunil Kumar Srivastava \\ Botanical Survey of India, Northern Regional Centre, Dehradun - 248195, India
}

\begin{abstract}
The rich flora of cold desert constitutes an incredible store house of plant genetic resources that contribute not only to the livelihoods of enormous number of forest dwelling but also to the various pharmaceuticals industry. The plant wealth of Ladakh in Jammu and Kashmir, Lahaul-Spiti in Himachal Pradesh and Nelang valley in Uttarakhand falls in cold desert region of North-West Himalaya. The floristic documentation of this area represents ca 1405 species, 490 genera under 98 families of flowering plants. A large number of species growing in this area are of medicinal and economic value and used by local inhabitants for curing their ailments. Floristic analysis, brief account of physiography, vegetation types and adaptations in the plants for their survival, endemism, threatened taxa, medicinal and economic plants have been discussed along with the threats and conservation strategies.
\end{abstract}

Key-words: Floristic, Diversity, Conservation, Cold Desert, India

\section{Introduction}

India occupies $2.4 \%$ of the world's land area, the second largest country in Asia and seventh in the world, has a total geographical area of about 329 million ha. India has a representation of 12 biogeographical provinces, five biomes and three bioregion domains (Udvardy 1975; Bailey 1989; Cox and Moore 1993). Of the world's 34 biodiversity hot spots, India shares four of them with the neighboring countries: (i) Western Ghats, (ii) The Himalayan hot spot, (iii) IndoBurma region and (iv) The Sundaland area.

The flora of India is both rich and diverse comprising about 46,340 species of plants already identified, and classified. This constitutes Angiosperms $(17,643)$, Gymnosperms (69), Pteridophytes (1236), Bryophytes (2451), Lichens (2268), Fungi (14,588), Algae (7182) and Virus/Bacteria (903), which accounts for about $11 \%$ of the total plant species of the world. This includes 99 National Parks, 600 Wildlife Sanctuaries and 16 biosphere reserves.

For correspondence, e-mail address: skshri08@rediffmail.com
Cold Desert is the $16^{\text {th }}$ Biosphere Reserve comprising an area of 7770 sq km and includes Pin Valley National Park and several other areas of Spiti valley (Anonymous 2009-10).

\section{Desert Ecosystem}

Desert ecosystem is characterized by low precipitation, arid lands with expanse of sands, rocks or salt, largely barren for sparse seasonal vegetal cover. It covers $2 \%$ of the total landmass in India which are categorized into three distinct types: (i) Sandy Thar Desert (west Rajasthan and adjoining areas of the state), (ii) Vast salt desert (Kutch in Rajasthan), and (iii) High altitude cold desert (Jammu and Kashmir, Himachal Pradesh and Uttarakhand).

\section{COLD DESERT}

The cold desert forms plateau extending from 4500-6000 m altitude in Trans-Himalayan rain shadow zone of western Himalayas. Cold deserts are characterized by extremely low temperature $\left(-45^{\circ} \mathrm{C}\right)$ and low rainfall (ranging from $500-600$ 


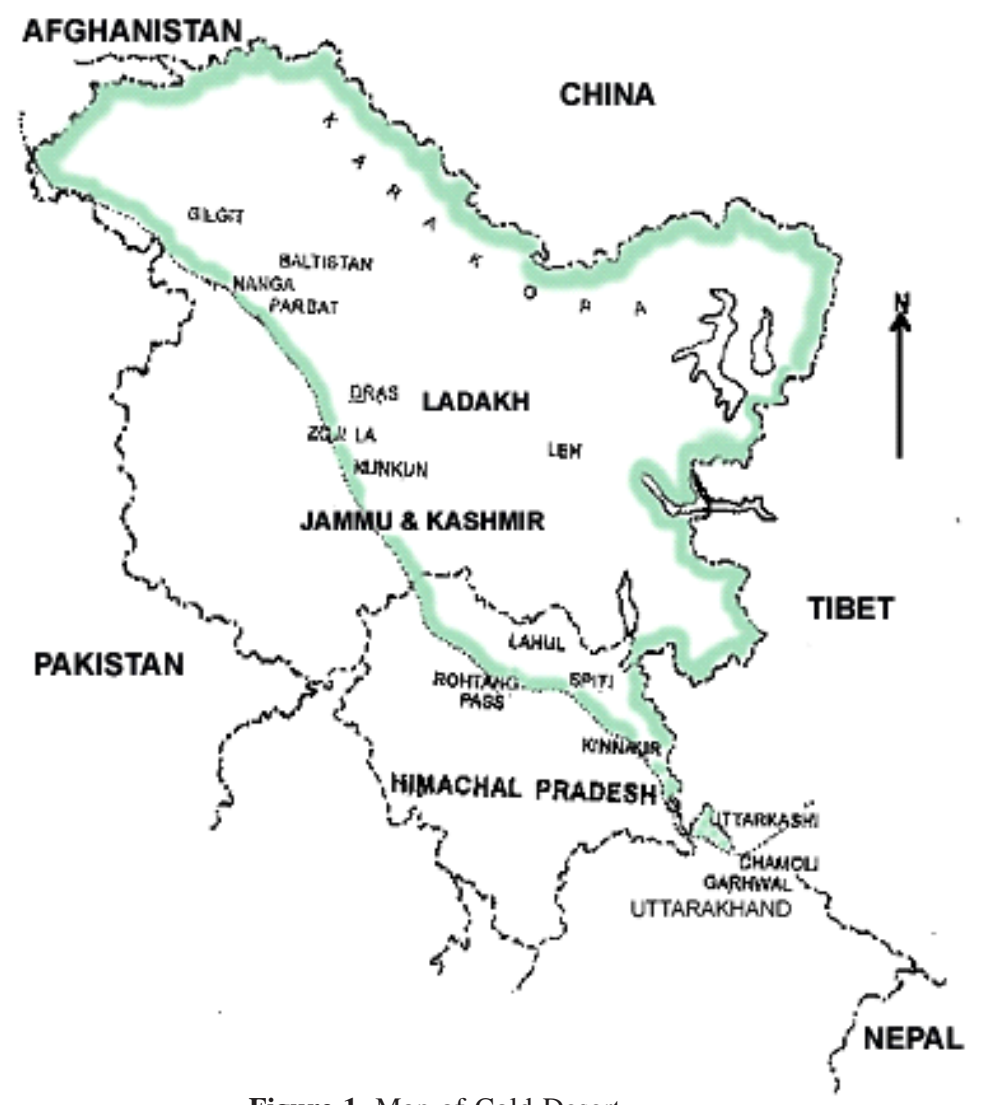

Figure 1. Map of Cold Desert.

mm annually). Increase in human pressure and activities pose serious threat to the survival of this ecosystem and its constituent plants and animals. This human pressure and over exploitation of natural resources have made the transHimalayan cold deserts one of the worlds most fragile and threatened ecosystems.

The cold desert covers an area of $c a .98,980 \mathrm{~km}^{2}$ in India and comes under the Trans-Himalayan zone. It covers Ladakh region in Jammu and Kashmir (82,655 km²), Lahaul-Spiti and Kinnaur in Himachal Pradesh (15000 sq km) and Nelang valley, Mana and Niti valley in Uttarakhand $\left(1000 \mathrm{~km}^{2}\right)$ (Fig. 1). Geologically the Himalayas fall into 3 series, northern, central and southern. The soils of Ladakh have been classified as grey, light arid, sandy or sandy loam of low fertility with appreciable quantities of clay at some places. The $\mathrm{pH}$ ranges between 7 and 11 (Bhat 1965). The climate is characterized by great extremes of heat and cold, coupled with excessive dryness. Absence of humidity helps to keep the atmosphere clear. In the summer, the heat during day time is so intense and it is so cold at night that the mountains crack and crumble.

\section{Vegetation}

Trans-Himalayan region supports very scanty and highly specialized vegetation, characteristic of cold desert. The vegetation of cold desert broadly categorized into three groups.

ALPINE

Plants restricted to moist regions, in depressions and slopes which are moistened by melting snow and glacial streams. The most conspicuous character of the vegetation is the cushion like habit of plants. It protects these plants from the intensely cold dry winds. The plant species of Delphinium, Aconitum, Potentilla, Anemone, Polygonum, Leontopodium, Taraxacum, Aster, Viola, Podophyllum, Impatiens, Astragalus, Geranium, Gentiana, Swertia, Saxifraga are common here.

\section{COLD DESERT FLORA}

Typical desertic elements are found in the areas beyond the transition zone. These areas receive none or very scanty rainfall with extreme fluctuation of diurnal temperature. Due 
to high velocity of winds, constantly blowing in these high altitude areas, the plants tend to become prostrate, thick woolly, cushion forming, bushy, hardy, spiny and with deep penetrating long roots and small leaves. Some common typical desert species are Thylacospermum caespitosum, Acantholimon lycopodioides, Echinops cornigerus, Lindelofia anchusoides, Tanacetum tibeticum, Nepeta floccose, Arnebia guttata, Lancea tibetica, Lepidium apetalum, Elaeagnus angustifolia, Potentilla anserina, Sedum ewersii, Saxifraga sibirica, Waldheimia tomentosa, Dianthus anatolicus, Oxytropis lapponica, Potentilla multifida, Plantago minima, Sedum tibeticum, Arabis tibetica, Corydalis crassifolia, etc.

\section{OASITIC VEGETATION}

The flora of Oasis represents vegetation near habitations and is cosmopolitan. The Oasitic elements comprise a variety of exotic as well as indigenous species, growing near habitation, along water courses, streams, nullah and in moist places. A few common elements are Lancea tibetica, Pedicularis longiflora, Arabidopsis himalaica, Ranunculus pulchellus, Geranium collinum, G. sibiricum, Medicago lupulina, Astragalus densiflorus, Rubus saxatilis, Sedum quadrifidum, Chenopodium foliosum, Mentha longifolia, Epilobium roseum, Nepeta tibetica, etc. The trees, with the exception of Hippophae, are practically all introduced. The commonest genera are Salix, Populus, Juglans, Morus, Pyrus and Prunus.

\section{Adaptation for Survival Strategies}

The plants of cold deserts exhibit a number of ecological, morphological and physiological adaptations which help them to counteract the impact of harsh climate prevailing in these regions. These plants are capable of establishing themselves in cold arid regions as far as there is dry soil or substratum available to provide them anchorage and also remain free from ice or snow just for few weeks in a year. Some peculiar adaptation strategies of these plants are discussed below.

\section{CUSHION-FORMING HABIT}

Cushion, clump or mat-forming habit is very common in cold desert plants. Such plants are perennial, short and sturdy with woody stem and deep root system capable of penetrating rock crevices and fissures to provide firm anchorage and nutrition to the plant. Such a habit protects from the strong wind action and its drying effects, strong thermal radiations, loss of water through transpiration, in maintaining the balance of temperature fluctuations between air and soil and from the continuous pressure of snow layer which may be several feet thick for months together. The typical plants exhibiting cushion habit are Acantholimon lycopodioides, Thylacospermum caespitosum, Arenaria bryophylla, and species of Astragalus, Androsace, Draba, Sedum, Saxifraga, etc.

\section{DIMINUTIVE OR MINIATURE HABIT}

Although the cold desert plants are generally dwarf and stunted, some of them are so significantly reduced that one may not even notice them in fields. Species like Pleurogyne brachyanthera, Gentiana thomsonii and Taraxacum bicolor are often barely 1-2 cm tall with a solitary flower. Ranunculus tricuspis, Anemone imbricata, Lancea tibetica and Saxifraga parva are some other small sized species. Few Saussurea species are an example of diminutive plants of cold desert. Astragalus heydei, Corydalis crassissima, Thermopsis inflata and Dracocephalum heterophyllum develop deep penetrating permanent root-stocks from which annual branches are produced and they bear leaves and flowers in clusters just above the stones or rocks.

\section{BUSHY HABIT}

The number of woody tall plants in cold arid region is exceedingly low. Caragana pygmaea, Ephedra gerardiana, Hippophae rhamnoides, Myricaria prostrata and Lonicera hispida form dense bushy habit with woody branches barely attaining $30-150 \mathrm{~cm}$.

\section{PROTECTIVE COVERING OF HAIRS}

Many species growing in cold deserts have very dense hairs forming a felt like coating on the entire surface of the exposed parts. These hairs act as a thermal blanket. Besides providing thermal security, they impart a silver-grey or white appearance to the plant which helps in reflecting the solar radiations reducing thereby the harsh impact of sun's rays. Astragalus munroi, Saussurea gossypiphora and Soroseris glomerata have profuse wool coating on the vegetative and floral parts.

\section{Reproductive Strategies}

The cold desert plants have to complete the entire reproductive cycle from the opening of buds to sprouting the leaves and 
flowers, fruiting and even dispersal of seeds. Thus, reproduction and dispersal among the plants inhabiting the cold deserts maintains the population of this scanty vegetation under the existing adverse conditions. The reproduction is accomplished both by seed formation and by the vegetative propagation.

Green leaves in presence of sunlight produces carbohydrates through photosynthesis, at the same time flower uses its energy for heating purposes which accelerates the growth of pollen and seeds.

The saucer shaped flowers of Anemone, Ranunculus, Saxifraga have highly reflective inner surface of petals. This shape acts as small dish antenna focusing the reflected light where stamens and carpels retain the heat gained through such radiation. The energy helps in pollination. Through which it conserve energy providing food for bees in the form of nectar. In this way, symbiotic relationship is formed between insect and plant in cold desert area.

\section{Floristic Diversity}

Kachroo et al. (1977) enumerated 611 species from Ladakh. Aswal and Mehrotra (1994) recorded 985 species from the Lahaul-Spiti in Himachal Pradesh. Based on recent collections, herbarium records and reports published, the flora of the cold desert comprises ca. 1405 species of flowering plants, distributed in 490 genera and 98 families, including 8 species of gymnosperms (Fig. 2) (Aitchison 1868; Watt G. 1881; Brandis 1884; Joshi 1952; Rau 1960; Nair 1964; Singh and Gohil 1972; Aswal and Mehrotra 1979, 1980a,b, 1981, 1983, 1985, 1994; Kapahi and Srin 1979; Srivastava et al. 1981; Balapure 1982; Misri 1982; Naqshi et al. 1989; Singh and Gupta 1990; Murti 2001; Chandrasekhar and Srivastava 2009). The most dominant families are Poaceae, Asteraceae, Caryophyllaceae and Brassicaceae (Fig. 3).

\section{Endemic Species}

Himalaya, being one of the hot spots representing the megacentre of endemism in Indian flora. The flora of the cold desert comprises ca. 1405 species; of these, several species confined their distribution to this biogeographical area. The species listed as endemic (Table 1) are found in the cold desert of the Indian Himalayan region and also on the land of international boundaries.

\section{Threatened Species}

The region of Cold Desert falls under the fragile ecosystem in Western Himalaya. The topography, physical features and harsh climatic conditions are the major threats to the habitat of these areas resulting into the depletion of various taxa represented in the ecosystem (Table 2). The criteria for assigning threatened categories to these species are based on

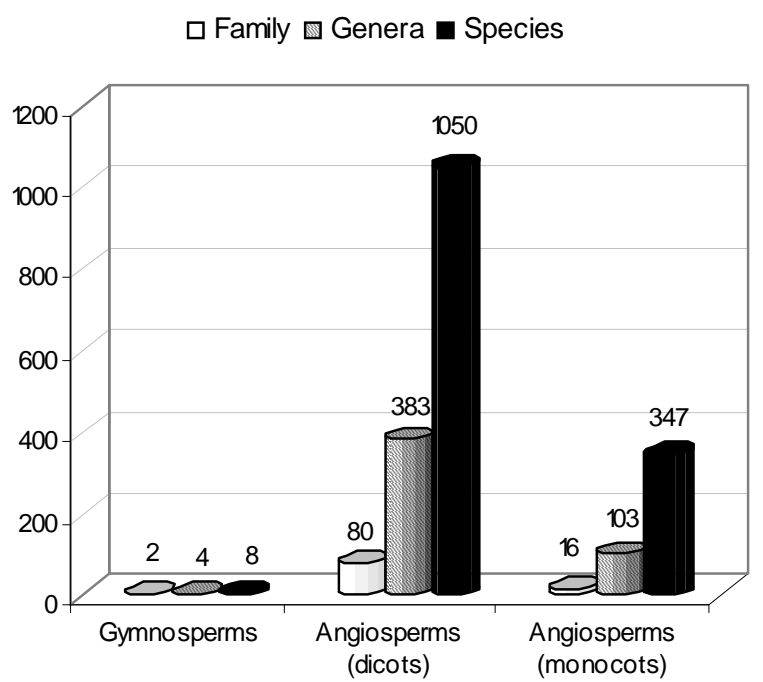

Figure 2. Status of plant groups in Cold Desert.

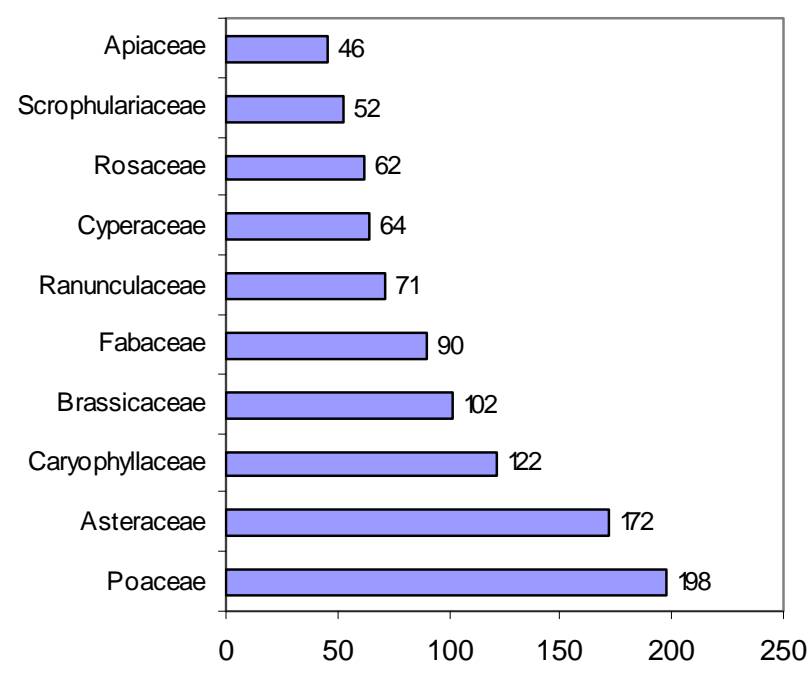

Figure 3. Ten dominant families of the Cold Desert. 
Table 1. Endemic species of cold desert.

\begin{tabular}{ll}
\hline Species & Family \\
\hline Allium loratum & Liliaceae \\
Anaphalis royleana & Asteraceae \\
Arenaria stracheyi & Caryophyllaceae \\
Astragalus munroi & Fabaceae \\
Astragalus zanskarensis & Fabaceae \\
Berberis ulcina & Berberidaceae \\
Christolea stewartii & Brassicaceae \\
Corydalis crassifolia & Fumariaceae \\
Dactylorhiza hatagirea & Orchidaceae \\
Draba cashmirica & Brassicaceae \\
Ferula jaeschkeana & Apiaceae \\
Lancea tibetica & Scrophulariaceae \\
Poa ladakhensis & Poaceae \\
Potentilla thomsonii & Rosaceae \\
Ranunculus trivedii & Ranunculaceae \\
Saussurea graminifolia & Asteraceae \\
Silene stewartii & Caryophyllaceae \\
Thalictrum rutaefolium & Ranunculaceae \\
Waldheimia stoliczkei & Asteraceae \\
\hline
\end{tabular}

the availability in the field, their local exploitation, herbarium record and data published in literature. It is worth mentioning that such species are to be thoroughly studied as per latest IUCN guidelines

\section{Invasive Species}

Invasive alien species are non-native that has the potential to harm the environment, economies, or human health and the second largest threat to plant diversity after habitat destruction. Aliens are also considered as Biological invaders (Mack et al. 2000). About 14 species are recognized under 12 genera and 9 families as invasive aliens in the flora of Cold Desert, viz., Tribulus terrestris, Sonchus asper, Sonchus oleraceous, Xanthium strumarium, Achyranthes aspera, Chenopodium album, Cuscuta reflexa, Datura stramonium, Solanum nigrum, Asphodelus tenuifolius, Echinochloa colona, Echinochloa crusgalli, Saccharum spontaneum and Typha angustata.

\section{Phytogeographical Affinities}

The flora of the cold desert represents number of plant species which are also found in the neighboring regions/countries. A
Table 2. Threatened species of cold desert.

\begin{tabular}{llc}
\hline Species & Family & $\begin{array}{c}\text { Threat } \\
\text { category }\end{array}$ \\
\hline Allium carolinianum & Liliaceae & $\mathrm{V}$ \\
Astragalus malacophyllus & Fabaceae & $\mathrm{V}$ \\
Cremanthodium decaisnei & Asteraceae & $\mathrm{EN}$ \\
Draba cachemirica & Brassicaceae & $\mathrm{V}$ \\
Eremurus himalaicus & Liliaceae & $\mathrm{V}$ \\
Galium tibeticum & Rubiaceae & EN \\
Geranium pseudo-aconitifolium & Geraniaceae & EN \\
Oxytropis sericopetala & Fabaceae & $\mathrm{V}$ \\
Poa ladakhensis & Poaceae & $\mathrm{CR}$ \\
Primula obtusiloba & Primulaceae & $\mathrm{V}$ \\
Rhodiola brunonii & Crassulaceae & EN \\
Rhodiola tibetica & Crassulaceae & EN \\
Saussurea bracteata & Asteraceae & CR \\
Stellaria pusilla & Caryophyllaceae & $\mathrm{V}$ \\
Thermopsis inflata & Fabaceae & $\mathrm{V}$ \\
Thlaspi cochlearioides & Brassicaceae & EN \\
Thylacospermum caespitosum & Caryophyllaceae & EN \\
Viola kunawarensis & Violaceae & $\mathrm{CR}$ \\
\hline
\end{tabular}

list of such plants known to occur in the adjoining countries is given below (Table 3).

Achyranthus aspera, Amaranthus spinosus, Arenaria serphyllifolia, Capsella bursa-pastoris, Convolvulus arvensis, Cynodon dactylon, Epilobium hirsutum, Lactuca orientalis, Lepidium virginicum, Ranunculus sceleratus, Spergularia rubra, Tribulus terrestris, Verbascum thapsus, etc. are also known to occur in hot desert ecosystem.

\section{Medicinal and Economically Potential Species}

Cold desert has rich wealth of plants having economic potential as crop, medicine, ornament and for other ethnobotanical uses. Number of plant species found in the area is being used in curing various ailments by the local people also known as 'Amchis system' of medicine and many species are used for various other purposes. Some of the important medicinal plants are Aconitum heterophyllum, Aconitum violaceum, Artemisia maritima, Arabis tibetica, Astragalus candolleanus, Berberis ulcina, Capparis spinosa, Carum carvi, Chenopodium botrys, Convolvulus arvensis, Dactylorhiza hatagirea, Dracocephalum heterophyllum, Ephedra gerardiana, Ferula jaeschkeana, Gentiana kurroo, Hippophae 
Table 3. List of cold desert plants also found in the neighboring regions/countries.

\begin{tabular}{|c|c|c|c|c|c|}
\hline Tibet & Afghanistan & Turkestan & China & Europe & U.S.A. \\
\hline $\begin{array}{l}\text { Aconitum } \\
\text { rotundifolium }\end{array}$ & Actaea acuminate & Arenaria serpyllifolia & Anaphalis busua & Adonis aestivalis & Agrostis stolonifera \\
\hline Anaphalis virgata & Anaphalis contorta & Artemisia laciniata & $\begin{array}{l}\text { Androsace } \\
\text { mucronifolia }\end{array}$ & $\begin{array}{l}\text { Arenaria } \\
\text { serpyllifolia }\end{array}$ & Aquilegia fragrans \\
\hline Anemone rupicola & $\begin{array}{l}\text { Androsace } \\
\text { rotundifolia }\end{array}$ & Chenopodium album & Anemone rivularis & $\begin{array}{l}\text { Artemisia } \\
\text { procumbens }\end{array}$ & $\begin{array}{l}\text { Arabidopsis } \\
\text { thaliana }\end{array}$ \\
\hline $\begin{array}{l}\text { Aquilegia } \\
\text { moorcroftiana }\end{array}$ & $\begin{array}{l}\text { Arabidopsis } \\
\text { thaliana }\end{array}$ & Dianthus anatolicus & $\begin{array}{l}\text { Aphragmus } \\
\text { oxycarpus }\end{array}$ & $\begin{array}{l}\text { Bupleurum } \\
\text { falcatum }\end{array}$ & $\begin{array}{l}\text { Arenaria } \\
\text { serpyllifolia }\end{array}$ \\
\hline $\begin{array}{l}\text { Arabidopsis } \\
\text { taraxacifolia }\end{array}$ & Artemisia gmelinii & Gagea kunawarensis & Arabis glandulosa & $\begin{array}{l}\text { Campanula } \\
\text { latifolia }\end{array}$ & Avena fatua \\
\hline Arabis tibetica & Aster flaccidus & Geranium collinum & $\begin{array}{l}\text { Artemisia } \\
\text { sieversiana }\end{array}$ & $\begin{array}{l}\text { Cardamine } \\
\text { impatiens }\end{array}$ & Barbarea vulgaris \\
\hline Arenaria festucoides & $\begin{array}{l}\text { Astragalus } \\
\text { coluteocarpus }\end{array}$ & $\begin{array}{l}\text { Lomatogonium } \\
\text { carinthiacum }\end{array}$ & Bromus pectinatus & $\begin{array}{l}\text { Carduus } \\
\text { edelbergii }\end{array}$ & Carduus edelbergii \\
\hline Arnebia guttata & Bergenia stracheyi & Melilotus alba & $\begin{array}{l}\text { Caragana } \\
\text { versicolor }\end{array}$ & $\begin{array}{l}\text { Chenopodium } \\
\text { glaucum }\end{array}$ & Carex orbicularis \\
\hline $\begin{array}{l}\text { Artemisia } \\
\text { macrocephala }\end{array}$ & Brassica nigra & Sagina saginoides & $\begin{array}{l}\text { Cardamine } \\
\text { macrophylla }\end{array}$ & $\begin{array}{l}\text { Eleocharis } \\
\text { palustris }\end{array}$ & Carum carvi \\
\hline Astragalus confertus & Campanula aristata & Trifolium pretense & Corydalis flabellata & $\begin{array}{l}\text { Epilobium } \\
\text { roseum }\end{array}$ & $\begin{array}{l}\text { Cerastium } \\
\text { vulgatum }\end{array}$ \\
\hline Astragalus gracilipes & Carex oliveri & Vaccaria pyramidata & $\begin{array}{l}\text { Cotoneaster } \\
\text { duthieanus }\end{array}$ & $\begin{array}{l}\text { Geranium } \\
\text { pratense }\end{array}$ & $\begin{array}{l}\text { Chenopodium } \\
\text { album }\end{array}$ \\
\hline Atriplex crassifolia & Carex pamirensis & & Elymus nutans & Juncus bufonius & $\begin{array}{l}\text { Chenopodium } \\
\text { botrys }\end{array}$ \\
\hline Braya thomsonii & Carex songorica & & Galium tibeticum & $\begin{array}{l}\text { Lamium } \\
\text { amplexicaule }\end{array}$ & $\begin{array}{l}\text { Convolvulus } \\
\text { arvensis }\end{array}$ \\
\hline Carex borii & Carum carvi & & Gentiana argentea & Mentha longifolia & Dactylis glomerata \\
\hline Carum carvi & Chorispora sabulosa & & $\begin{array}{l}\text { Heracleum } \\
\text { lanatum }\end{array}$ & Origanum vulgare & Eleocharis palustris \\
\hline Corydalis crassifolia & Clematis orientalis & & Iris decora & Oxyria digyna & Elymus repens \\
\hline Crepis multicaulis & Codonopsis ovate & & $\begin{array}{l}\text { Kobresia } \\
\text { capillifolia }\end{array}$ & $\begin{array}{l}\text { Polygonum } \\
\text { hydropiper }\end{array}$ & $\begin{array}{l}\text { Epilobium } \\
\text { angustifolium }\end{array}$ \\
\hline $\begin{array}{l}\text { Delphinium } \\
\text { brunonianum }\end{array}$ & Cousinia thomsonii & & Lactuca dissecta & $\begin{array}{l}\text { Potentilla } \\
\text { anserine }\end{array}$ & Galium aparine \\
\hline Festuca olgae & Draba oreades & & $\begin{array}{l}\text { Lepidium } \\
\text { apetalum }\end{array}$ & Primula sibirica & Geranium pratense \\
\hline
\end{tabular}

rhamnoides, Hyoscyamus niger, Meconopsis aculeata, Papaver nudicaule, Picrorhiza korrooa, Podophyllum hexandrum, Rheum emodi.

The wild edible fruits of Capparis spinosa, Cotoneaster falconeri, Ephedra gerardiana, Hippophae rhamnoides, Ribes orientale and Rosa hookeriana are consumed by local people. Plants or their parts are cooked as vegetables from Allium carolinianum, A. stoliezki, Chaerophyllum acuminatum, Chenopodium album, Cicer microphyllum, Eremyrus himalaicus, Mentha longifolia and Rumex acetosa.

Astragalus chlorostachys, A. peduncularis, Caragana versicolor, Cicer microphyllum, Hippophae rhamaoides ssp. Turkestanica, Medicage falcata, Myricaria albiflora, Myrtama elegans, Populus ciliata, Salix denticulata, S. fruticulosa and
Trigonella emodi are used as fodder and fuel purposes. The wood of Juniperus recurva, Populus ciliata and Salix denticulata are used for timber and implements. Arnebia euchroma, Geranium pratense and Onosma hispidum are used as dye. The incense and perfumes are obtained from Chrysanthemum pyrethroides, Delphinium brunonianum and Waldheimia glabra. Bushes of Hippophae rhamnoides are used for fencing.

\section{Threats}

The extreme climatic conditions i.e. sub-zero temperature with great diurnal fluctuations, scanty and erratic rainfall, heavy 
snowfall, howling winds, ultraviolet radiation, desiccating exposure to the sun, landslides, snow slides, avalanches, soil erosion etc. are the natural factors causing damage to the vegetation. Local people depend for fuel wood on the plants growing in the area. They uproot and dry the shrubby species of Lonicera, Rosa, Salix, Caragana, Myricaria, Ephedra, etc. and use them resulting into a loss of vegetal cover. The green vegetation consisting of Cicer microphyllum, Saussurea jacea, Thalictrum foetidum, Poa annua, Festuca olgae, etc. are collected as fodder and stored for winter stall-feeding of livestock. Migratory livestock of sheep and goats graze on the unrivalled pasture and destroy the vegetation through physical injury to herbaceous vegetation, seedling and saplings. Fire caused by human activities is also one of the injurious threats to vegetation.

\section{Conservation Strategies}

- Grazing by migratory livestock in the pastures and alpine meadows should be banned completely.

- Species which are suggested as vulnerable or endangered should be protected and multiplied under both in-situ and ex-situ conservation.

○ Introduction of fuel wood plants in the area, through social forestry should be done in order to provide alternate fuel sources during the winter months and so to allow the shrubby species like Hippophae, Myrtama, Myricaria, Rosa and Salix flourish naturally.

o To establish botanical garden in selected sites in Ladakh and Spiti area of cold desert region under ex-situ conservation.

\section{Gaps and Future Strategies}

○ To undertake through survey and collection of plants in unexplored area.

○ Documentation of the flora of cold desert including Algae, Fungi, Lichen, Bryophytes and Pteridophytes is required.

- Identification of under exploited plants used by local people.

○ Recording of rare and threatened species for conservation purposes and species specific survey to relocate the critically endangered taxa.
- Spatial maps of the distribution of economically important of species that becomes either rare or fragmented should be developed.

- An integrated research approach should be made among botanist, agronomist, anthropologist, plant chemist and allied specialist for better understanding of the interrelationship of primitive societies.

\section{References}

Aitchison J.E.T. 1868. Lahaul, its flora and vegetable products. Journal of Linnaean Society of Botany 10: 69-101.

Anonymous. 2009-10. Annual Report. Ministry of Environment and Forests, Government of India, New Delhi, India.

Aswal B.S. and Mehrotra B.N. 1979. New records of plants from Himachal Pradesh, India. Indian Journal of Forestry 2(4): 322.

Aswal B.S. and Mehrotra B.N. 1980a. Contribution to the flora of Lahaul Valley (North-West Himalaya)-I. Some new plant records. Indian Journal of Forestry 3(2): 154-155.

Aswal B.S. and Mehrotra B.N. 1980b. Contribution to the flora of Lahaul Valley (North-West Himalaya)-II. Some new plant records. Journal of Economic and Taxonomic Botany 1: 115-117.

Aswal B.S. and Mehrotra B.N. 1981. Contribution to the flora of Lahaul Valley (North-West Himalaya)-III. A note on the nomenclature of plants. Journal of Economic and Taxonomic Botany 2: 236.

Aswal B.S. and Mehrotra B.N. 1983. Contribution to the flora of Lahaul Valley (North-West Himalaya)-IV. Some new plant records. Indian Journal of Forestry 6(4): 314-318.

Aswal B.S. and Mehrotra B.N. 1985. Contribution to the flora of Lahaul Valley (North-West Himalaya)-V. Phytogeographical aspects. Journal of Economic and Taxonomic Botany 7(2): 299-307.

Aswal B.S. and Mehrotra B.N. 1994. Flora of Lahaul-Spiti. Bishen Singh Mahendra Pal Singh, Dehradun, India.

Bailey R.G. 1989. Ecoregions of the continents. Environmental Conservation 16: 307-309.

Balapure K.M. 1982. Some new records and additional localities of plants from Ladakh. Journal of Economic and Taxonomic Botany 3(1): 187-191.

Bhat G.M. 1965. The Soils of Kashmir. Bulletin of Agriculture Department, Jammu and Kashmir Government, Srinagar, India.

Brandis D. 1884. The Forest Flora of North-West and Central India. Bishen Singh Mahendra Pal Singh, Dehradun, Dehradun, India.

Chandrasekhar K. and Srivastava S.K. 2009. Flora of Pin Valley National Park, Himachal Pradesh. Botanical Survey of India, Kolkata.

Cox C.B. and Moore P.D. 1993. Biogeography: An Ecological and Evolutionary Approach. Blackwell Scientific Publications, London, UK.

Joshi A.C. 1952. Aquatic vegetation of Lahaul. The Palaeobotanist 1: 277-280. 
Kachroo P., Sapru B.L., and Dhar U. 1977. Flora of Ladakh. Bishen Singh Mahendra Pal Singh, Dehradun, India.

Kapahi B.K. and Sarin Y.K. 1979. Contribution to the botany of Lahaul. Journal of Bombay Natural History Society 87: 274-279.

Mack R.N., Simberloff D., Lonsdale W.M., Evans H., Clout M. and Bazzaz F.A. 2000. Biotic invasions: causes, epidemiology, global consequences, and control. Ecological Application 10: 689-710.

Misri B. 1982. A preliminary survey of grasses and legumes of Ladakh. Australian Plant Introduction Review 30: 37-45.

Murti S.K. 2001. Flora of Cold Desert of Western Himalaya 1. Monocotyledons. Botanical Survey of India, Calcutta.

Nair N.C. 1964. Some plant records for Lahaul-Spiti. Bulletin of Botanical Survey of India 6: 151-153.

Naqshi A.R., Malla N.Y. and Dar G.H. 1989. Plants of Ladakh, Nubra. Journal of Economic and Taxonomic Botany 13(3): 539-560.
Rau M.A. 1960. On a collection of plants from Lahaul. Bulletin of Botanical Survey of India 2: 45-56.

Singh G. and Gohil R.N. 1972. Some new records to the flora of Ladakh. Journal of Bombay Natural History Society 73(3): 487-490.

Singh R.P. and Gupta M.K. 1990. Soil and vegetation study of Lahaul-Spiti cold desert of Western Himalaya. Indian Forester 116: 785-790.

Srivastava T.N., Shah N.C., Badola D.P. and Gupta O.P. 1981. New records of flowering plants of Ladakh. Indian Journal of Forestry 4(2): 138-141.

Udvardy M.D.F. 1975. A Classification of the Biogeographical Provinces of the World. IUCN Occasional Papers 18, Morges, Switzerland.

Watt G. 1881. Notes on the vegetation of Chamba State and British Lahaul. Journal of Linnaean Society of Botany 18: 368-382. 